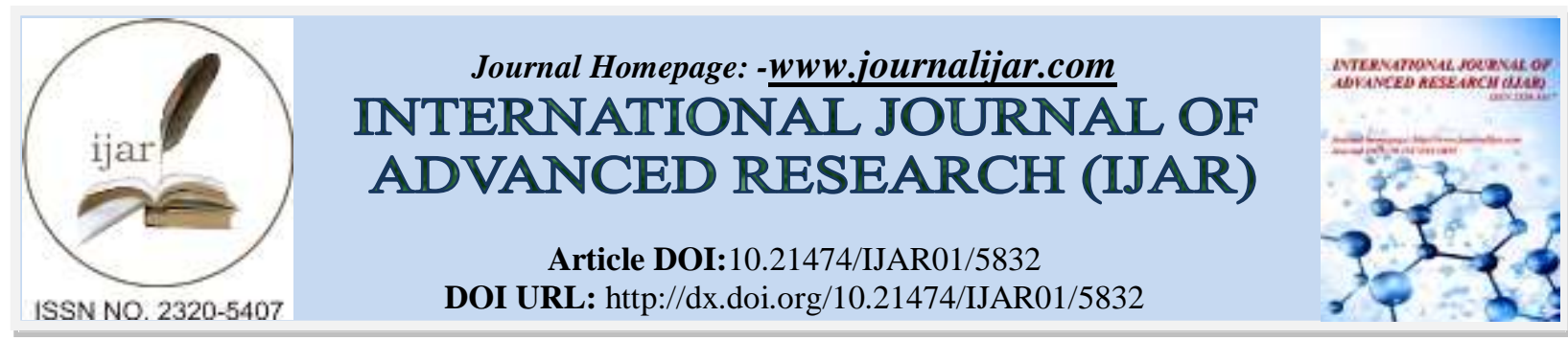

RESEARCH ARTICLE

\title{
A COMPARATIVE ANALYSIS OF FOOT ANTHROPOMETRY IN ADULT MALE POPULATION OF HARYANA, INDIA.
}

\author{
Thakyal Sanjeev ${ }^{1}$, Khanna Munish ${ }^{2}$ and Rustagi $\mathrm{SM}^{3}$. \\ 1. Assistant Professor Department of Anatomy Pt JLNGMC\&H Chamba HP \\ 2. Associate Professor Department of Anatomy Pt JLNGMC\&H Chamba HP. \\ 3. Associate Professor Department of Anatomy VMMC \&H, Delhi.
}

\section{Manuscript Info}

Manuscript History

Received: 11 September 2017

Final Accepted: 13 October 2017

Published: November 2017

Key words:-

Footedness, foot indices, adult male, Haryana.

\section{Abstract}

The present study was aimed at measuring foot indices of 150 male subjects and thereby providing a baseline anthropometric data that is of significance in forensic science, orthopedics and other allied health sciences. The study was carried out on male subjects 18years and above. Footedness was analyzed by using the criterion, like kicking the ball or preference of the subject to use a particular foot while initiating walking. Of the subjects analyzed, majority of them were found to be right footed.

Copy Right, IJAR, 2017,. All rights reserved.

\section{Introduction:-}

Each of the human foot is a highly complex structure with 26 major bones and more than 30 synovial articulations ${ }^{1}$. These articulations are supported by ligaments, tendons and intrinsic muscles of the foot. This complex anatomy of the foot is meant to sub serve the primary function of the foot which is mobility or locomotion. While both our feet are structurally same, functionally, they are slightly different. It has been observed that there is a natural inherent tendency to use one of the foot more often than the other and this foot which is preferably used for the motor activities is the is the preferred foot or the dominant foot and the foot that is used for support the body weight is the non preferred foot ${ }^{2}$. With a complex structure and dynamic function human foot has been subject of various experimental studies. These studies are able to measure, simultaneously both the kinematics and dy namic structural behaviors of the foot during gait $^{3}$.

Footedness in human is overwhelmingly right sided ${ }^{4}$ and various studies have been done on lateralization encompassing multiple professional and scholarly disciplines such as philosophy, physical and social anthropology, medical genetics, biochemistry, evolutionary biology aesthetics and cognitive psycholog $y^{5}$.

Footedness has been implicated as a risk factor for the development of pathology in that particular limb. This is because most individuals place a greater demand on their preferred foot during various motor activities. Thus long term mechanical stress acting homogenously on the preferred lower limb may cause injuries and hazards to that limb.

\section{Materials \& Methods:-}

The present study was conducted in department of anatomy at M.M.I.M.S.R Mullana, Ambala on 150 males students of 18yrs and above. The subjects were chosen on simple random basis from among the medical students at M.M.I.M.S.R Mullana, Ambala.

Prior informed consent was for the study was obtained in English and vernacular language. 
Inclusion criterion:- following population was included in the study

1. Only those who were willing to participate were included

2. Subjects above 18 yers of age

3. Subjects were drawn from amongst the students of M.M.I.M.S.R Mullana, Ambala

\section{Exclusion criterion:-}

1. Subjects with apparent physical foot anomalies, inflammation, trauma, deformities and surgery (if any) were excluded.

2. Subjects below $18 \mathrm{yrs}$ of age were excluded

3. Subjects other than medical students of MMIMSR, Ambala.

The arithmetic mean of all the foot parameters of 150 males medical students were statistically analyzed using students t-test.The right and left feet of right and left footed subjects were analyzed statistically using student t-test, tabulated and co-related with each other.

\section{Ethical Justification:-}

Only those subjects who volunteered to participate in the study after informed consent were taken and the data was kept confidential. Study did not cause any financial burden on the subjects or the institute; therefore the study is ethically justified.

\section{Observations:-}

Present study was conducted on 150 males. Foot anthropometric measurements and footedness of each foot of the subject were measured and checked by using the criteria given. Mean age of subjects in the study was 19.14years. The measurements and comparison of results for the right and left feet of right and left footed males who participated in the study were done as per following details

Measurements and indices :-The following indices were measured for the 150 male subjects:

1. Foot length, measured between acropodian* and pternion**

2. Foot breadth, measured between medial and lateral margin

3. Foot height, distance from floor to the pheasant***

4. Foot index:Foot breadth/Foot length $\mathrm{x} 100$

\section{Foot Height:-}

The average right foot height(Shaifaly et $\mathrm{al}^{6,7}$ ) was found to be $7.04 \pm 0.75 \mathrm{~cm}$ (Table 1.1) and that of left foot was $7.20 \pm 0.73 \mathrm{~cm}$. The left foot height was found to be significantly more than that of right foot height $(\mathrm{p}=0.002)$.

Table 1.1:- Mean foot parameters of 150 male students

\begin{tabular}{|l|l|l|l|}
\hline $\begin{array}{l}\text { Parameter } \\
(\mathrm{cm})\end{array}$ & Right foot $^{\#}$ & Left foot & p-value \\
\cline { 2 - 3 } & Mean \pm SD & Mean \pm SD & \\
\hline Foot height(FH) & $7.04 \pm 0.75$ & $7.20 \pm 0.73$ & 0.002 \\
\hline Foot breadth(FB) & $9.24 \pm 0.57$ & $9.54 \pm 0.54$ & 0.120 \\
\hline Foot length(FL) & $25.86 \pm 1.33$ & $26.05 \pm 1.50$ & 0.007 \\
\hline $\begin{array}{l}\text { Foot index(FI) } \\
\text { (FB/FBX100) }\end{array}$ & $36.76 \pm 1.92^{\#}$ & $36.68 \pm 2.03$ & 0.590 \\
\hline
\end{tabular}

* Shaifaly et al ${ }^{6,7}$

*Acropodian: most forwardly projecting point on the head of $1^{\text {st }}$ or $2^{\text {nd }}$ toe

**Pternion: most backwardly projecting point on heel

***Pheasant: point where top of the foot meets the front of the leg

\section{Foot Breadth:-}

The average right foot breadth (Shaifaly et $\mathrm{al}^{6,7}$ )was found to be $9.49 \pm 0.57 \mathrm{~cm}$ and average left foot breadth $9.54 \pm 0.54$. The left foot breadth was found to be more than that of right foot breadth and results was statistically not significant. 


\section{Foot length:-}

Theaverage right foot length(Shaifaly et $\mathrm{al}^{6,7}$ ) was observed to be $25.86 \pm 1.33$ and that of left foot length was $26.05 \pm 1.5 \mathrm{~cm}$. The left foot length was found to be significantly more than that of right foot length $(\mathrm{p}=0.007)$.

\section{Foot Index:-}

The total average foot index of right foot was $36.76 \pm 1.92 *\left(\right.$ Shaifaly et $\left.\mathrm{al}^{6,7}\right)$ and that of left foot was $36.68 \pm 2.03$. The average right foot index was found to be more than that of average left foot index. But the values were not significant $(\mathrm{p}>0.005)$.

\section{Footedness or the foot preference:-}

Majority of the subjects, 140 males out of total 150 subjects were found to be right footed (93.33\%). The remaining 10 males $(6.67 \%)$ preferred their left foot to kick the ball.

\section{Foot indices in Left footed subjects:-}

The following were foot indices in left footed male subjects (Table 1.2):

Table 1.2:- Mean foot parameters in left footed males $(\mathrm{N}=10)$

\begin{tabular}{|l|l|l|l|}
\hline $\begin{array}{l}\text { Parameter } \\
(\mathrm{cm})\end{array}$ & Right foot & Left foot & p-value \\
\cline { 2 - 4 } & Mean \pm SD & Mean \pm SD & 0.260 \\
\hline $\begin{array}{l}\text { Foot height } \\
\text { FH) }\end{array}$ & $6.60 \pm 0.74$ & $6.83 \pm 0.58$ & 0.673 \\
\hline $\begin{array}{l}\text { Foot breadth } \\
(\text { FB })\end{array}$ & $9.67 \pm 0.86$ & $9.73 \pm 0.73$ & 0.172 \\
\hline $\begin{array}{l}\text { Foot length } \\
\text { (FL) }\end{array}$ & $25.80 \pm 1.33$ & $26.03 \pm 1.11$ & 0.874 \\
\hline $\begin{array}{l}\text { Foot index } \\
\text { (FI) } \\
(\text { FB/FLx100) }\end{array}$ & $37.49 \pm 2.88$ & $37.38 \pm 2.41$ & \\
\hline
\end{tabular}

\section{Foot height:-}

In left footed males, the average right foot height was found to be $6.60 \pm 0.74 \mathrm{~cm}$ and that of left foot height was $6.83 \pm 0.58 \mathrm{~cm}$. The mean left foot height was found to be more than that of mean right foot height. But no significant differences was observed in the foot height.

\section{Foot breadth:-}

In left footed males, the average right foot breadth was found to be $9.67 \pm 0.86 \mathrm{~cm}$ and average left foot breadth was $9.73 \pm 0.73 \mathrm{~cm}$. The left foot breadth was found to be more than that of right foot breadth. No significant difference was observed in the two measurements.

\section{Foot length:-}

In left footed males, the average right foot length was observed to be $25.80 \pm 1.33 \mathrm{~cm}$ and that of left foot was $26.03 \pm 1.11 \mathrm{~cm}$. The left foot length was found to be more than that of right foot length. No significant difference was observed.

Foot index:-

In left footed males, the average right foot index of left footed males was $37.49 \pm 2.88$ and that of left foot was $37.38 \pm 2.11$.

\section{Foot indices in Right footed subjects:-}

The following were foot indices in right footed subjects (Table 1.3):

Table 1.3:- Mean foot parameters in right footed males( $\mathrm{N}=140$; Shaifaly et $\left.\mathrm{al}^{6,7}\right)$.

\begin{tabular}{|l|l|l|l|}
\hline $\begin{array}{l}\text { Parameters } \\
(\mathrm{cm})\end{array}$ & Right Foot & Left foot & p-value \\
\cline { 2 - 4 } $\begin{array}{l}\text { Foot height } \\
(\mathrm{FH})\end{array}$ & $7.07 \pm 0.75$ & Mean \pm SD & 0.004 \\
\hline $\begin{array}{l}\text { Foot breadth } \\
\text { (FB) }\end{array}$ & $9.48 \pm 0.55$ & $7.22 \pm 0.73$ & 0.138 \\
\hline Foot length & $25.68 \pm 1.33$ & $9.53 \pm 0.53$ & 0.012 \\
\hline
\end{tabular}




\begin{tabular}{|l|l|l|l|}
\hline (FL) & & & \\
\hline $\begin{array}{l}\text { Foot Index } \\
\text { (FI) }\end{array}$ & $36.70 \pm 1.84$ & $36.63 \pm 2.00$ & 0.610 \\
(FB/FLX100) & & & \\
\hline
\end{tabular}

\section{Foot height:-}

The average foot height was found to be $7.07 \pm 0.75 \mathrm{~cm}$ and that of left foot height was $7.22 \pm 0.73 \mathrm{~cm}$. The left foot height was found to be significantly more than that of right foot height $(\mathrm{p}=0.004)$.

\section{Foot breadth:-}

The average right foot breadth was found to be $9.48 \pm 0.55 \mathrm{~cm}$ and average left foot breadth was $9.53 \mathrm{~cm} \pm 0.53 \mathrm{~cm}$. No significant difference was observed in foot breadth.

\section{Foot length:-}

The average right foot length was observed to be $25.86 \pm 1.33 \mathrm{~cm}$ and that of left foot was $26.06 \pm 1.53 \mathrm{~cm}$. The left foot length was found to be significantly more than that of right foot length ( $\mathrm{p}==0.012$ ).

\section{Foot Index:-}

The average foot index of right foot was $36.70 \pm 1.84$ and that of left foot was $36.63 \pm 2.00$. The average right foot index was found to be more than average left foot index. But the difference was not significant.

\section{Discussion:-}

The foot dimensions vary between populations and can be attributed to factors such as genetics, environment and social conditions.

In the present study, with regards to the bilateral differences, foot length on left side is significantly longer (Table 2.1). In coincidence with our study, JaydipSenet $\mathrm{al}^{19}$ and Mukta rani et $\mathrm{al}^{20}$ also observed significantly longer feet on left side in males. Our similar findings could be due to similar population studied (sub groups of Indian population) and similar sample sizes. However, Barnabas et $\mathrm{al}^{13}$, Oladipo et $\mathrm{al}^{18}$ and Agnihotri et $\mathrm{al}^{12}$ have found longer feet on right side in males. These differences could be due to different geographical population studied. Barnabas et al ${ }^{13}$ and Oladipo et $\mathrm{al}^{18}$ conducted their study on Nigerians whereas Agnihotri et $\mathrm{al}^{12}$ studied the Mauritian population. In variance to the studies mentioned Mannual Bob et $\mathrm{al}^{14}$ have found mean foot length to be almost equal on both the right and left side.

Table 2.1:- Comparison of mean Foot length of males of present study group with previous study

\begin{tabular}{|c|c|c|c|c|c|}
\hline \multirow[t]{2}{*}{ Author } & \multirow[t]{2}{*}{ Population } & \multirow[t]{2}{*}{ No. } & \multicolumn{2}{|l|}{$\begin{array}{l}\text { Foot length } \\
(\text { Mean } \pm S D)\end{array}$} & \multirow[t]{2}{*}{ p-value } \\
\hline & & & $\begin{array}{l}\text { Right } \\
\text { Foot }\end{array}$ & Left Foot & \\
\hline Present study & $\begin{array}{ll}\begin{array}{l}\text { Male } \\
\text { students }\end{array} & \text { Medical } \\
\end{array}$ & 150 & $25.86 \pm 1.33$ & $26.05 \pm 1.50$ & $\mathrm{P}<0.005$ \\
\hline $\begin{array}{l}\text { KewalKrishan et } \\
\mathrm{al}^{10}\end{array}$ & Himachal Pradesh & 123 & $24.72 \pm 1.19$ & $24.70 \pm 1.1$ & $\mathrm{p}>0.005$ \\
\hline 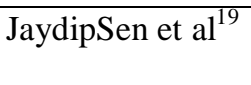 & $\begin{array}{l}\text { Bengalee } \\
\text { (Rajbanshi) }\end{array}$ & 175 & $23.95 \pm 1.10$ & $24.01 \pm 1.10$ & $\mathrm{p}<0.001$ \\
\hline $\begin{array}{l}\text { Mukta Rani et } \\
\mathrm{al}^{20}\end{array}$ & $\begin{array}{l}\text { Students of Delhi } \\
\text { college }\end{array}$ & 150 & $23.24 \pm 1.58$ & $23.46 \pm 1.59$ & \\
\hline Oladipo et $\mathrm{al}^{18}$ & Nigerians & 66 & $25.12 \pm 0.51$ & $25.08 \pm 0.35$ & $\mathrm{p}<0.05$ \\
\hline Agnihotri et al $^{12}$ & Mauritius & 125 & $26.17 \pm 1.05$ & $26.14 \pm 1.06$ & \\
\hline $\begin{array}{l}\text { Manuel Bob et } \\
\mathrm{al}^{15}\end{array}$ & Nigerians & 249 & $26.92 \pm 1.02$ & $26.92 \pm 0.13$ & \\
\hline $\begin{array}{l}\text { Barnabas and } \\
\text { Elukpo }^{13}\end{array}$ & Nigerians & 250 & $28.39 \pm 1.73$ & $26.42 \pm 1.60$ & $\mathrm{p}>0.05$ \\
\hline Ozden $\mathrm{H} \mathrm{el} \mathrm{al}^{9}$ & Turkey & 294 & $26.00 \pm 1.34$ & $26.04 \pm 1.36$ & \\
\hline
\end{tabular}

However, Mauritian males have longer feet than males of our study. In present study values were less than the Nigerians (Barnabas et $\mathrm{al}^{13}$ and Manuel Bob et $\mathrm{al}^{15}$ ), and Turkey population (Ozden et $\mathrm{al}^{9}$ ). 
Agie at $\mathrm{al}^{3}$ documented longer feet than our study but they conducted their research on Croatian males and they did not consider bilateral differences. But in contrast, Patel SM et $\mathrm{al}^{11}$ in his study on Gujrati population has observed smaller feet (mean $24.44 \mathrm{~cm}$ ) in males The longest feet reported in all studies in available literature belong to those studied by Barnabas et $\mathrm{al}^{13}$. They have studied the Nigerain population and this racial difference could be the reason for the increased dimension observed.

Table2.2:-Comparision of mean foot breadth of males present study group with previous studies.

\begin{tabular}{|c|c|c|c|c|c|c|}
\hline \multirow[t]{2}{*}{ Author } & \multirow[t]{2}{*}{ Population } & \multirow[t]{2}{*}{ Gender } & \multirow[t]{2}{*}{ No. } & \multicolumn{2}{|c|}{$\begin{array}{l}\text { Foot breadth } \\
(\text { Mean } \pm \text { SD) }\end{array}$} & \multirow[t]{2}{*}{$\mathrm{p}$-value } \\
\hline & & & & $\begin{array}{l}\text { Right } \\
\text { Foot }\end{array}$ & Left Foot & \\
\hline Present study & $\begin{array}{l}\text { Medical } \\
\text { students }\end{array}$ & $\mathrm{M}$ & 150 & $9.49 \pm 0.57$ & $9.54 \pm 0.54$ & $\mathrm{P}>0.005$ \\
\hline 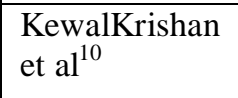 & $\begin{array}{l}\text { Himachal } \\
\text { Pradesh }\end{array}$ & $\mathrm{M}$ & 123 & $9.52 \pm 0.61$ & $9.5 \pm 0.61$ & $p>0.005$ \\
\hline $\begin{array}{l}\text { KewalKrishan } \\
\text { et } \mathrm{al}^{14}\end{array}$ & $\begin{array}{ll}\text { Noth } & \text { Indian } \\
\text { Gujjars } & \end{array}$ & $\mathrm{M}$ & 1040 & $9.26 \pm 2.10$ & $8.91 \pm 2.06$ & \\
\hline $\begin{array}{l}\text { JaydipSen et. } \\
\mathrm{al}^{19}\end{array}$ & $\begin{array}{l}\text { Bengalee } \\
\text { (Rajbanshi) }\end{array}$ & $\mathrm{M}$ & 175 & $9.89 \pm 0.50$ & $9.90 \pm 0.50$ & $\mathrm{p}<0.001$ \\
\hline $\begin{array}{ll}\text { Mukta } & \text { Rani } \\
{\text { et. } \mathrm{al}^{20}}\end{array}$ & $\begin{array}{l}\text { Students of } \\
\text { Delhi college }\end{array}$ & $\mathrm{M}$ & 150 & $8.52 \pm 0.67$ & $8.66 \pm 0.68$ & \\
\hline Oladipo et $\mathrm{al}^{18}$ & Nigerians & $\mathrm{M}$ & 66 & $9.25 \pm 0.28$ & $9.13 \pm 0.31$ & $\mathrm{p}<0.05$ \\
\hline $\begin{array}{l}\text { Agnihotri et } \\
\mathrm{al}^{12}\end{array}$ & Mauritius & $\mathrm{M}$ & 125 & $9.63 \pm 0.54$ & $9.62 \pm 0.54$ & \\
\hline $\begin{array}{l}\text { Manuel } \\
\text { et } \mathrm{al}^{15}\end{array}$ & Nigerians & $\mathrm{M}$ & 249 & $9.87 \pm 0.53$ & $9.87 \pm 0.53$ & \\
\hline $\begin{array}{l}\text { Barnabas and } \\
\text { Elukpo }^{13}\end{array}$ & Nigerians & $\mathrm{M}$ & 250 & $9.02 \pm 0.72$ & $9.09 \pm 0.94$ & $p>0.05$ \\
\hline Ozden $\mathrm{H} \mathrm{el} \mathrm{al}^{9}$ & Turkey & $\mathrm{M}$ & 294 & $9.41 \pm 0.99$ & $9.41 \pm 0.99$ & \\
\hline
\end{tabular}

According to Table 2.2 on comparing present study with previous studies, the feet of the 300 medical students considered in our study are more wide than the feet of Delhi population(Mukta Rani et $\mathrm{al}^{20}$ ), north Indian Gujjars(Kewal Krishan ${ }^{14}$ ), Nigerains (Oladipo et $\mathrm{al}^{18}$ and Barbanas et al) and Turkish population(Ozden $\left.\mathrm{H} \mathrm{et} \mathrm{al}^{9}\right)$. In present study, values were less than the north Indian Himachal population (Kewal Krishan ${ }^{10}$ ), RajbhanshiBangalee population (JaydipSen et $\mathrm{al}^{19}$ ), Mauritius population (Agnihiotri et $\mathrm{al}^{12}$ ), Nigerians (Manuel Bob et $\mathrm{al}^{15}$ ). Nigerians $\left(\right.$ Oladipoet $\mathrm{al}^{18}$ ) males have less wider feet than the present study males

Table 2.3:- Comparison of Mean foot height of males of present study group with previous studies

\begin{tabular}{|c|c|c|c|c|c|c|}
\hline \multirow[t]{2}{*}{ Author } & \multirow[t]{2}{*}{ Population } & \multirow[t]{2}{*}{ Gender } & \multirow[t]{2}{*}{ No. } & \multicolumn{2}{|c|}{$\begin{array}{l}\text { Foot height } \\
(\text { Mean } \pm \text { SD) }\end{array}$} & \multirow[t]{2}{*}{$\mathrm{p}$-value } \\
\hline & & & & $\begin{array}{l}\text { Right } \\
\text { Foot }\end{array}$ & Left Foot & \\
\hline Present study & $\begin{array}{l}\text { Medical } \\
\text { students }\end{array}$ & $\mathrm{M}$ & 150 & $9.49 \pm 0.57$ & $9.54 \pm 0.54$ & $\mathrm{P}>0.005$ \\
\hline Manna et $\mathrm{al}^{8}$ & Bengalese & $\mathrm{M}$ & 200 & $8.00 \pm 0.81$ & $7.96 \pm 0.84$ & $p>0.05$ \\
\hline 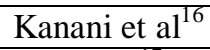 & Iranian & $\mathrm{M}$ & 160 & \multicolumn{2}{|c|}{$8.22 \pm 0.55$} & \\
\hline Bari et $\mathrm{al}^{17}$ & Malaysian & $\mathrm{M}$ & 129 & $5.52 \pm 0.70$ & $5.87 \pm 0.69$ & \\
\hline
\end{tabular}

In males, left feet are significantly higher than right sided feet, however; Manna et $\mathrm{al}^{8}$ (Bangalese) have found mean right feet height more than the left in males . Our findings are in accordance with Bari et $\mathrm{al}^{17}$ (Malaysians) where mean left feet height is higher in males (Table 2.3). The difference as compared to our study could be due to the fact that they have studied 5 to $6 y r$ old Malaysian children as opposed to the adult group in our study. In variance to our 
study, the Iranian males studied Kannani et al (Iranian) have much higher feet. This may be because of racial and genetic factors.

Table 2.4:- Comparison of Mean Foot Index of Males of Present study group with previous studies

\begin{tabular}{|c|c|c|c|c|c|c|}
\hline \multirow[t]{2}{*}{ Author } & \multirow[t]{2}{*}{ Population } & \multirow[t]{2}{*}{ Gender } & \multirow[t]{2}{*}{ No. } & \multicolumn{2}{|l|}{$\begin{array}{l}\text { Foot Index } \\
(\text { Mean } \pm \text { SD) }\end{array}$} & \multirow[t]{2}{*}{ p-value } \\
\hline & & & & $\begin{array}{l}\text { Right } \\
\text { Foot }\end{array}$ & Left Foot & \\
\hline Present study & $\begin{array}{l}\text { Medical } \\
\text { students }\end{array}$ & $\mathrm{M}$ & 150 & $36.75 \pm 1.92$ & $36.68 \pm 2.03$ & $\mathrm{P}>0.005$ \\
\hline $\begin{array}{l}\text { JaydipSen et. } \\
\mathrm{al}^{19}\end{array}$ & $\begin{array}{l}\text { Bengalee } \\
\text { (Rajbanshi) }\end{array}$ & $\mathrm{M}$ & 175 & $41.32 \pm 1.80$ & $41.30 \pm 1.80$ & \\
\hline $\begin{array}{l}\text { KewalKrishan } \\
\text { et } \mathrm{al}^{14}\end{array}$ & $\begin{array}{l}\text { Himachal } \\
\text { Pradesh }\end{array}$ & $\mathrm{M}$ & 123 & $38.89 \pm 2.2$ & $38.65 \pm 2.10$ & \\
\hline $\begin{array}{l}\text { Agnihotri et. } \\
\mathrm{al}^{12}\end{array}$ & Mauritius & $\mathrm{M}$ & 125 & $36.90 \pm 0.54$ & $36.91 \pm 0.54$ & \\
\hline $\begin{array}{l}\text { Barnabas and } \\
\text { Elukpo }^{13}\end{array}$ & Nigerians & $\mathrm{M}$ & 250 & $34.17 \pm 2.67$ & $34.28 \pm 2.19$ & $\mathrm{P}<0.005$ \\
\hline
\end{tabular}

Table 2.4 depicts the mean right foot index was found to be more in males as compared to the left side. This coincided with studies of JaydipSenet $\mathrm{al}^{19}$ on BangaleseRajbhashi population and KewalKrishan et $\mathrm{al}^{10}$ on Himachali population. However, Barnabas et $\mathrm{al}^{13}$ on Nigerians and Agnihotri et $\mathrm{al}^{12}$ observed higher mean foot indices on left side in males. But our results disagree with Agnihotriet $\mathrm{al}^{12}$ (Mauritian population) who observed higher foot index on left side in males. This may be because of environmental and genetic differences.

The sample of our study considered of 150 male medical students. Out of 150 males studied 140 (93.33\%) were right footed and 10 out of 150 were found to be left footed (6.6\%). Yamaner et $\mathrm{al}^{2}$ in his study of evaluating foot morphology depending on foot preference has documented 328 of 407 male football players to be right footed and 79 to be left footed. Carey et al found $79 \%$ right footed and $21 \%$ left footed out of 236 players they studied in France world cup 1998. However, Zverev et al and Spry et $\mathrm{al}^{21}$ have reported a mixed footed group of $10.7 \%$ and $9.21 \%$ respectively. Zverev et al reported $81 \%$ right footed and $8.3 \%$ left footed of the 205 (112 males and 93 females) cases studied and Spry et $\mathrm{al}^{21}$ documented 39 right leg dominant and 30 left leg dominant of 76 cases studied. In comparision to all these studies mentioned we have observed higher preponderance of right sided individuals $(90 \%)$.

Table 2.5:- Comparison of Mean Foot dimensions of right foot preference group in males

\begin{tabular}{|l|l|l|l|l|l|}
\hline Author & \multirow{2}{*}{ No. } & Side & \multicolumn{2}{|l|}{ Right Foot Preference Group } \\
\cline { 4 - 6 } & & & Foot height & Foot breadth & Foot length \\
\hline Present study & 140 & RF & $7.07 \pm 0.75$ & $9.48 \pm 0.55$ & $25.85 \pm 1.33$ \\
\cline { 3 - 6 } & & LF & $\begin{array}{l}7.22 \pm 0.73 \\
(\mathrm{p}<0.05)\end{array}$ & $9.53 \pm 0.52$ & $\begin{array}{l}26.05 \pm 1.53 \\
(\mathrm{p}<0.05)\end{array}$ \\
\hline Yamaner et al $^{2}$ & 328 & RF & $6.17 \pm 0.59$ & $10.14 \pm 0.47$ & $26.77 \pm 1.08$ \\
\cline { 3 - 6 } & & LF & $6.19 \pm 0.64$ & $\begin{array}{l}10.20 \pm 0.58 \\
(\mathrm{p}<0.05)\end{array}$ & $\begin{array}{l}26.84 \pm 1.12 \\
(\mathrm{p}<0.05)\end{array}$ \\
\hline
\end{tabular}

In the present study, all the dimensions of left foot (foot height, foot breadth and foot length) of left foot were more than that of right foot in the right foot preference group. These results are in accordance with Yamaner et al in which left foot parameters were also larger on left side. These findings could be suggestive of the fact that the non 
dominant i.e. left sided measurement are more in the right footed individuals as the left side is used more for maintaining posture and balancing the weight of the body.

The right and left foot height of present study group were height than that of Yamaner et al on Turkish foot ball players. But measurements of right and left foot breadth and foot length of present study group were lower than that of Yamaner et al group. This may be because of racial and sample difference. So, it can be inferred from the study that Turkish players feet were much wider and longer than the Indians in the right footed group.

Table 2.6:-Comparison of Mean Foot dimensions of Left foot preference group in males

\begin{tabular}{|l|l|l|l|l|l|}
\hline Author & \multirow{2}{*}{ No. } & Side & \multicolumn{2}{|l|}{ Right Foot Preference Group } \\
\cline { 3 - 6 } & & & Foot height & Foot breadth & Foot length \\
\hline Present study & 10 & RF & $6.60 \pm 0.74$ & $9.67 \pm 0.86$ & $25.80 \pm 1.33$ \\
\cline { 3 - 6 } & & LF & $6.83 \pm 0.58$ & $9.73 \pm 0.73$ & $26.03 \pm 1.11$ \\
\hline Yamaner et al $^{2}$ & 79 & RF & $6.15 \pm 0.61$ & $10.01 \pm 0.48$ & $26.48 \pm 1.24$ \\
\cline { 4 - 6 } & & LF & $6.10 \pm 0.66$ & $\begin{array}{l}10.11 \pm 0.53 \\
(\mathrm{P}<0.05)\end{array}$ & $26.53 \pm 1.28$ \\
\hline
\end{tabular}

When the left foot preference was examined it was seen that all the somatometric measurements (foot height, foot breadth and foot length) of the left foot were more than that of right foot. However, these findings cannot be considered to be statistically significant as the sample size is too small $(\mathrm{n}=10)$. Our results coincided with the studies of Yamaneret al. ${ }^{2}$ in which left foot parameters were also larger on the left side except the foot height which was larger on right side.

The right and left foot height of left foot preference group of present study were higher than that of the Yamaner et al on Turkish football players. But the measurements of right and left foot breadth and foot length of present study group were lower than that of Yamaner et al group. This may be due to racial and sample differences.

\section{Conclusion:-}

On comparison of the foot indices of the present study group with the other local and international study groups it was found that

1. The mean foot length in the present study is longer than the mean foot length of the other local population groups studied in India; however, it is lesser when compared with other international study groups.

2. No specific correlation for the mean foot breadth could be found when it was compared with mean foot breadth with some of the local population groups in India and other international study groups.

3. The mean foot height was found to be higher than the local and international study groups

4. The foot index in the present study was found to be less than the local population groups in India; however, when compared with international study groups no specific conclusion could be drawn as it was almost same for one study and was higher than the other study group.

5. Mean foot dimensions of the right footed and left footed subjects were compared with a single international study and it was found these indices were higher in our study group.

\section{Competing interests:-}

There are no competing interests.

\section{Acknowledgements:-}

We would like to thank the subjects for their cooperation and the staff of anatomy department, MMIMSR, Ambala, India.

Author contributions:-

1. SanjeevThankyal

Was the chief investigator.

2. MunishKhanna(corresponding author) 
Analyzed and interpreted the data

\section{Shifalli M Rustagi}

Gave the guidance

\section{Biblography:-}

1. Ibinabo FD, Didia C. Sexual dimorphism in foot dimensions among adult Nigerians. J bio anthropol 2009;3(1):1-8

2. Yamaner F, Karacabey K, Kavlak Y, Sevindi T. Foot morphology of Turkish football players according to the foot preference.

3. Agie A, Nikolie V, Mijovie B. Foot anthropometry and morphology phenomenon. CollAnthropol 2006;30(4):815-21

4. Carey PD, Smith G, Smith TD, Shepherd WJ, Skriver J, Ord L et al. Footedness in world soccer. J sports sci $2001 ;(19): 855-64$

5. Porac C, Coren S. lateral preferences and human behavior. Springer-verlag:283.

6. Shaifaly M Rustagi, Patnaik VV Gopichand, SanjeevThakyal. A Study of foot anthropometry in right footed Indian Population. Medicolegal-Update, 2013; (1)130-35

7. ShaifalyMadanRustagi, SanjeevThakyal, PatnaikVVGopichand. Foot Index in Right Footed Adults.Journal of Clinical and Diagnostic Research. 2014 Jun, Vol-8(6): AM01

8. Manna I, Pradhan D, Ghosh S, Kumar S, Dhara P. A comparative study of foot dimensions between adult male and female and evaluation of foot hazarfs due to using of footwear. J Physiolanthropol 2001; 20(4):241-46

9. Ozden H, Balci Y, Demitstru C, Turgut A, Ertugrul M. Stature and sex estimate using foot and shoe dimensions. For scilnt 2005; 147: 181-84.

10. Krishan K, Sharma A. Estimation of stature from dimensions of hands and feet in a north Indian population. $\mathrm{J}$ of forensic and legal medicine 2007;14:327-32.

11. Patel SM, Shah SV, Patel SV. Estimation of height from measurements of foot length in Gujrat region. J Anatsoc of India 2007;56(1):25-7

12. Agnihotri AK, Shukla SM, Purwar B. Determination of sex from foot measurements. J forensic med 2007;2(1).

13. Danborno B, Elukpo A. Sexual Dimorphism in hand and foot length, Indices, Stature-ratio and relationship to height in Nigerians. Internet J Forensic Sci 2008;3(1)

14. Krishan K. Determination of stature from foot and its segments in a north Indian population. $\mathbf{J}$ forensic med pathol 2008 Dec;29(4):297-303

15. Bob Manuel IFD, C. Didia. Sexual dimorphism in foot dimensions among adult Nigerians. The internet J Bio anthropol 2009;3(1)

16. Kanani JM, Mortazavi SB, Khavanin A, Mirzai R, Rasulzadeh Y, Mansurizadeh M. Foot anthropometry of 1825 year old Iranian male students. J scientific research 2010;62-9.

17. Bari SB, Othman M, SallehMohd. N. Foot anthropometry for shoe design among preschool children in Malaysia. Pertanika J socsci Hum 2010;18(1):69-79.

18. Oladipo G, Bob-Manuel I, Ezenatein G. Quantativecomaparision of foot anthropometry under different weight bearing conditions amongst Nigerians. J Bio anthropol 2010;3(1)

19. Sen J, Kanchan T, Passi N. Sex estimation from foot dimensions in indigenous Indian population. J of foresensicsci 2011jan;56(1)148-153.

20. Rani M, Tyagi AK, Ranga VK, Rani Y, Murari A. Stature estimation from foot dimensions. J Punjab acad forensic Med toxicology 2011 Feb 6;11(1):1-7

21. Spry S, Zebas C, Visser M. What is Leg dominance. ISBS $1993: 165-68$. 